\title{
Married Dispensation in Pressing Efforts of Divorce Numbers
}

\author{
Abdul Mutalip ${ }^{*}$ and Rozihan ${ }^{* *}$ \\ *) Student of Master of Law, Faculty of Law, Universitas Islam Sultan Agung (UNISSULA) \\ and Secretary of the Central Java Religious High Court, E-mail: \\ alif1970azkia2001@gmail.com \\ **) Faculty of Islamic Religion, Universitas Islam Sultan Agung
}

\begin{abstract}
.
The purpose of this study is to determine the factors and judges' considerations that influence the application for the grant of dispensation of marriage, as well as the role of dispensation of marriage in an effort to reduce the divorce rate. The research method used is juridical-sociological, juridical, which discusses research using laws and regulations related to marriage dispensation. The sociological approach is used to find out and understand how the judge's consideration factors in granting a marriage dispensation request. From the results of the study concluded that the factors causing the submission of applications for dispensation of marriage include pregnancy outside of marriage, concerns of parents about their children, economic factors and educational factors. The basis for the judge's consideration in granting dispensation to marriage is that there is no prohibition on marriage, physical, mental, biological, sociological and financial maturity in a state of urgency (pregnancy out of wedlock) the desire/agreement of both parties. While efforts to dispensate marriage in an effort to reduce the divorce rate are not yet certain, it can actually increase the divorce rate due to the unstable mental and psychological stability of children in fostering a household.

Keywords: Married; Dispensation; Divorce.
\end{abstract}

\section{Introduction}

Marriage is one very important aspect of human life. It even becomes a basic need for every normal human being. Without marriage, a person's life will be imperfect and more than that, violate his nature. Because Allah SWT., Has created his creatures in pairs. Prophet Muhammad SAW., Also reminded that marriage is the sunnah. Therefore those who carry out marriage follow his sunnah. ${ }^{1}$

A legal marriage results in the association of men and women in a respectful manner according to the position of humans as honorable beings. ${ }^{2}$ In essence, the marriage involves the families of both parties, but the dominant role in determining the direction and purpose of the marriage is the husband and wife couple.

The life wave of husband and wife in married life is very dynamic. Not a single family lives according to its wishes, without the ever-changing waves of problems. One of the abilities of a family in dealing with household problems can be determined by the maturity of the husband and wife. ${ }^{3}$

Those who are mature, both physically and psychologically, must have considered before making decisions about the continuation of their family. of

\footnotetext{
${ }^{1}$ Alam, H. Andi Syamsu. (2005) Usia Ideal Memenuhi Dunia Perkawinan. Jakarta: Kencana Mas Publishing House. p.18

2 Basyir, Ahmad Azhari. (1999). Hukum Perkawinan Islam, Yogyakarta: UII Press. p.1

3Ibid. p.16-17
} 
course this will be different from an immature couple. They will not be able to manage the emotions that arise so often without consideration decide to end their domestic life.

In Chapter I, Article 1 of Act No.1 of 1974, it is explained that what is meant by marriage is a physical and spiritual bond between a man and a woman as husband and wife with the aim of forming a prosperous, eternal family based on the Almighty God. Marriage has certain procedures and conditions that vary in each region and must be fulfilled in its implementation. ${ }^{4}$

In article 2 of the Compilation of Islamic Law, the philosophical foundation of marriage in accordance with Islamic teachings is emphasized without reducing the philosophical foundation of marriage based on Pancasila as regulated in Article 1 of Act No. 1 of 1974, that the philosophical foundation of national marriage is Pancasila, by linking marriage based on the first principle, namely Belief in the one and only God. This philosophical foundation is emphasized and expanded in article 2 of the Compilation of Islamic Law, which basically contains: marriage is solely to obey Allah's orders, carrying out marriage is worship, and the marriage bond is miitsaaqan gholidzan. ${ }^{5}$

Act No. 16 of 2019 concerning Amendments to Act No. 1 of 1974 concerning Marriage adheres to the principle that the prospective husband and wife must have mental and physical maturity in order to be able to marry, so in article 7 paragraph (1) of Act No. 16 of 2019 has determined the age limit for marrying both men and women, namely 19 years and if there is a deviation from the age requirement of the marriage, the new marriage can take place after receiving a dispensation from the court. Marriage dispensation is submitted by the parents of the prospective groom and/or prospective bride to the Religious Court so that their children who have not reached the age of marriage can be granted dispensation.

Among the reasons that are often put forward in the application for dispensation is that the relationship between the prospective groom and the prospective bride is very close, so that it is no longer possible to postpone the implementation of the marriage, or even both of them have already engaged in conjugal relations outside of marriage. So that parents are worried that their children will fall further into acts that are against Islamic law.

Religious Courts in adjudicating cases applying for dispensation of marriage often consider the two conditions, the fade that occurs as a result of child marriage/early marriage and the marriage that will occur if the marriage dispensation is rejected. The Panel of Judges often accepts applications for dispensation of marriage because it considers that the fade that will occur if the dispensation of marriage is rejected is greater than that that occurs due to early marriage, which is likely to damage the offspring and honor of the two prospective brides.

Termination of marriage is a legal term used in the Marriage Law to describe divorce or the end of a marital relationship between a man and a woman

\footnotetext{
${ }^{4}$ Ramulyo, Idris. (1996). Hukum Perkawinan Indonesia. Jakarta: Budi Aksara. p.5

${ }^{5}$ Harahap, M.Yahya. (2005) Kedudukan Kewenangan dan Acara Peradilan Agama Undang-Undang Nomor 7 Tahun 1989. Jakarta: Sinar Grafika.p.38
} 
who has been living as husband and wife. For couples who marry at an early age, in general the couple is not yet mentally and psychologically mature, so there is a possibility that they will not be able to manage the emotions that arise so that often without careful consideration, they decide to end their domestic life.

Child marriage is a very complex issue, it is not enough to just look at it from one point of view, there are basic and principal things that should be considered in child marriage, namely relating to the safety of the soul of the child, the continuation of children's education and the safety of offspring and more importantly, the psychological maturity of the child that can affect his family relationships later. In this case, suppressing the child divorce rate should be a concern.

\section{Research Methods}

The method used in this research is juridical-sociological.The juridical approach will discuss research using laws related to dispensation of marriage, which are contained in Act No. 1 of 1974 and Number 16 of 2019, Compilation of Islamic Law and others. Sociological approach, this approach is used to find out and understand how the factors considered by the judge in granting the application for dispensation of marriage.

\section{Results and Discussion}

\subsection{Factors Affecting Marriage Dispensation}

From the results of the research conducted, several factors were found to be the cause of proposed dispensation of marriage. In this case, based on the results of interviews with the Head of the Religious Courts, Deputy Chairmen of the Religious Courts and Judges of the Religious Courts in the work units of the High Religious Courts in Central Java, it can be concluded that the rampant applications for dispensation of marriage are dominated by factors:

- Unwed pregnancy

- Parents' concern for their children

- Economy

- Education. ${ }^{6}$

According to Islamic legal terms, marriage is also known as marriage, which is a very strong bond or aqad. ${ }^{7}$ Marriage or marriage in Arabic fiqh literature is called by two words, namely nikah and zawaj. ${ }^{8}$ The word marriage according to Arabic has two meanings, namely in the real sense (essence) and in a figurative sense (majaaz). ${ }^{9}$ Meanwhile, according to the Compilation of Islamic Law, divorce is one of the causes of a marriage breakdown. This is in accordance with the

\footnotetext{
${ }^{6}$ Interview with the Head of the Religious Courts and Judges of the Religious Courts in the work unit of the High Religious Courts in Central Java

${ }^{7}$ Istiqamah. (2011). Hukum Perdata di Indonesia. Makassar: Alauddin Press. p.76

${ }^{8}$ Syarifuddin, Amir. (2006). Hukum Perkawinan Islam di Indonesia: Antara Fiqh Munakahat dan Undang-Undang Perkawinan. Jakarta: Kencana. p.35

${ }^{9}$ Usman, Rachmadi. (2006). Aspek-Aspek Hukum Perorangan \& Kekeluargaan di Indonesia, Jakarta: Sinar Grafika. p.268
} 
provisions of Article $113 \mathrm{KHI}$, which stipulates that a marriage is broken due to 3 (three) reasons, namely death, divorce, and a court decision.

The lack of readiness of a husband and wife in building their household is mostly due to factors of age and minimal experience. The readiness of women to conceive is so thin due to the average age of 13-15 years that it is always the cause of the increase in infant mortality after a girl starts menstruating does not mean that she is physically ready to produce. Usually there are still a few more years, before the puberty process is over. ${ }^{10}$

Young married couples have not yet reached maturity, both psychologically and physically. Domestic failure at a young age is very likely to occur, it is because their souls are not yet capable of thinking about and solving problems that arise in the world of marriage. In addition, for young women who have become pregnant after marriage, it is very possible that pregnancy poisoning or infant death occurs, because their uterus is not yet able to work optimally. ${ }^{11}$

Other than that, Low religious understanding and a bad environment provide room for teenagers to have free sex. Without thinking and thinking about the consequences, teenagers commit acts that are prohibited by religion. These actions can make children who are not old enough get pregnant outside of marriage. Getting married is the best solution in order to cover up family disgrace and to save the future of the mother and the future baby. The reason for this urgent matter is that there is no other choice and the marriage is very forced to be carried out. 12

One of the things supporting parents' concerns about children can also be seen from the socio-cultural factors of society, especially in rural areas who feel uncomfortable if girls who have turned 16 years old and do not continue higher education but do not have a mate or life partner, so we Often they find that young marriages occur because their parents are afraid that their children will be said to be spinster and get married immediately. ${ }^{13}$

\subsection{Judges' Considerations in Granting Applications for Marriage Dispensation}

A judge's decision is a statement which the judge, as a State official who is given the authority to do so, is pronounced in court and aims to end or settle a case or dispute that occurs between the parties. It is not only pronounced what is called a decision, but also a written statement which is then pronounced by the judge at trial. ${ }^{14}$ Meanwhile, the position of a judge who gives a decision is one of the predicates attached to a person who has a special job and specifications in the

\footnotetext{
${ }^{10}$ Fatmawati. (2008). Penyelesaian Perkara Cerai Talak dan Cerai Gugat di Pengadilan Agama Pinrang. Scription. Makassar: Fakulty Syariah dan Hukum UIN Alauddin.p.17-18

11Ummu Kalsum. (2017). Pengaruh Dispensasi kawin Terhadap Tingkat Perceraian Di Pengadilan Agama Watampone Kelas I A. Scription. Makassar: Fakulty Syariah dan Hukum UIN Alauddin. p.43 ${ }^{12}$ Electronic Interview with Uray Gapima Aprianto, S.Ag. MH, Chair of the Kajen Religious Court, Kajen, 3 September 2020.

${ }^{13}$ Electronic Interview with Drs. Muhammad Dihyah Wahid, Head of the Temanggung Religious Court, Temanggung, 2 September 2020.

${ }^{14}$ Mertokusumo, Sudikno. (1998). Hukum Acara Perdata Indonesia. Yogjakarta: Libery. p.174
} 
field of law and justice so that many intersect with issues regarding legal freedom and justice in the context of decisions on cases being made. ${ }^{15}$ Based on the results of research conducted through electronic interviews with the Head of the Religious Courts, Deputy Chairmen of the Religious Courts, and Judges at the Religious Courts for the jurisdiction and work units of the High Religious Courts in Central Java, the judges' considerations in granting applications for dispensation of marriage are several reasons, namely:

- There is no marriage prohibition

- Maturity in terms of physical, mental, biological, and sociological and financial.

- In a state of urgency (Pregnant outside of marriage)

- The desire or agreement of both parties

From the reasons mentioned above, it can be said that the judge's consideration in determining the dispensation of marriage is to prioritize the benefit and to emphasize the principle of benefit for the parties, especially for the child. A marriage dispensation request is granted if it is related to principles and understandingmaqhasid syari'ah which is oriented and aims to establish commands and prohibitions for the benefit of mankind in the world and in the hereafter.

According to the author, if it is related to the maqasid syari'ah theory and the theory of legal certainty, as a consequence of the Indonesian State adopting the rule of law, ${ }^{16}$ The factors for determining the dispensation of marriage are among others because The safety factor of the child's soul (Hifzun Nafs), Continuation factors and protection of children's education/intellect (Hifzun alAql), and Hereditary safety factors related to the protection of offspring (Hifzun al-Nasl). In addition, dispensation of marriage is actually given to make the child born good for the family, society and the environment, especially in terms of obtaining a clear lineage. So that the status of a child born from a legal marriage (with a request for dispensation of marriage), also becomes a legal child according to law.

\subsection{Dispensation of Marriage in an Effort to Reduce the Divorce Rate}

Divorce comes from the word divorce which has the affix per. Divorce according to language means separation or breaking up as husband and wife. ${ }^{17}$ So divorce is the breaking of the marriage bond between husband and wife for certain reasons. Divorce in fiqh terms is called talak or furkah. The meaning of divorce is to open ties, cancel agreements, while furqah means divorce, namely the opposite of gathering. Then the word is used by fiqh experts as a term which means divorce between husband and wife. ${ }^{18}$

\footnotetext{
15Kamil, Ahmad. (2012). Filsafat Kebebasan Hakim. Jakarta: Prenadamedia Group. p.169

16Rika Marlina, Pembagian Kekuasaan Dalam Penyelenggaraan Pemerintahan Di Indonesia, Jurnal Daulat Hukum Volume 1 No. 1 Maret 2018 : $171 \quad$ - 178 , http://jurnal.unissula.ac.id/index.php/RH/article/view/2631/1980

${ }^{17}$ Ministry of National Education, Big Dictionary of Indonesian Language Center, Jakarta: PT Gramedia Pustaka Utama, 2008, p. 261.

18Soemiaty. (1999). Hukum Perkawinan Islam dan Undang-Undang Perkawinan, Yogyakarta: Liberty. p.103
} 
In the general explanation of the Revision of the Marriage Law, it is explained that increasing the age of marriage for women aims to anticipate child marriage, because the definition of a child according to Act No. 23 of 2002 concerning Child Protection is a person who has not reached the age of 18 (eighteen) years. In addition to anticipating child marriage, increasing the age of marriage for women also aims to reduce the divorce rate, get healthy and quality offspring, reduce the risk of maternal and child mortality, and to fulfill children's rights in the form of right to good development, get assistance from parents. , as well as accessing the highest possible education. ${ }^{19}$

The role of dispensation of marriage in an effort to reduce the divorce rate is a dilemma problem, because several divorce cases filed by ex-marriage dispensation spouses, indeed their marriage dispensation is on average because the actual marriage has not been desired because of the factor of being pregnant first and to cover up their final shame. a marriage dispensation is proposed. Although not all ex-remarried dispensation products return to court to seek divorce. ${ }^{20}$ So it can be said that the role of dispensation of marriage in an effort to suppress the divorce rate is not very effective because not a few couples who have received dispensation of marriage experience problems and eventually divorce because of the couple's maturity/maturity factor as well as the economic factor of the couple. ${ }^{21}$

According to the authors of attendance, Act No. 16 of 2019 concerning Amendments to Act No. 1 of 1974 Concerning Marriage and the Regulation of the Supreme Court of the Republic of Indonesia Number 5 of 2019 concerning Guidelines for Adjudicating Applications for Marriage Dispensation, as a new legal product and practically cannot confirm that with the dispensation of marriage it can reduce the divorce rate, in fact it can increase the divorce rate due to the unstable mental and psychological condition of children in building a household. But of course this can be resolved in the hope that the marriage age limit will be increased according to the revision of the Marriage Law which has just been added if in the process of examining cases, the dispensation of marriage is carried out in a serious, thorough and comprehensive manner so that the bride and groom can build a good household. However, if on the contrary, in the process of examining cases of marriage dispensation is carried out carelessly, it will in fact increase the divorce rate. So in principle, giving dispensation of marriage must be done carefully with various factors to consider.

\section{Conclusion}

The results of the study concluded that the factors causing the submission of application for dispensation of marriage were pregnancy outside of marriage, parents' concerns about their children, economic factors, and educational factors.

\footnotetext{
19 General Elucidation of Act No. 16 of 2019 concerning Amendments to Act No. 1 of 1974 concerning Marriage

${ }^{20}$ Electronic Interview with Drs. H. Ahmad Husni Tamrin, MH, Deputy Chairman of the Kebumen Religious Court, Kebumen, 3 September 2020.

${ }^{21}$ Electronic Interview with Dra. Hj. Sri Rokhmani, MHI, Deputy Chairman of the Pemalang Religious Court, Kebumen, 3 September 2020.
} 
The basis for the judge's consideration in granting dispensation to marriage is that there is no prohibition on marriage, maturity from a physical, mental, biological, and sociological and financial perspective, in a state of urgency (pregnancy outside of marriage), and the desire or agreement of both parties. While efforts to dispensate marriage in an effort to reduce the divorce rate are not yet certain, it can actually increase the divorce rate due to the unstable mental and psychological stability of children in fostering a household.

\section{References}

Journal:

[1] Rika Marlina, Pembagian Kekuasaan Dalam Penyelenggaraan Pemerintahan Di Indonesia, Jurnal Daulat Hukum Volume 1 No. 1 Maret 2018: 171 - 178, http://jurnal.unissula.ac.id/index.php/RH/article/view/2631/1980

Books:

[1] Alam, H. Andi Syamsu. (2005). Usia Ideal Memenuhi Dunia Perkawinan. Jakarta: Kencana Mas Publishing House

[2] Basyir, Ahmad Azhari. (1999). Hukum Perkawinan Islam, Yogyakarta: UII Press

[3] Fatmawati. (2008). Penyelesaian Perkara Cerai Talak dan Cerai Gugat di Pengadilan Agama Pinrang. Scription. Makassar: Fakulty Syariah dan Hukum UIN Alauddin

[4] Harahap, M.Yahya. (2005) Kedudukan Kewenangan dan Acara Peradilan Agama Undang-Undang Nomor 7 Tahun 1989. Jakarta: Sinar Grafika

[5] Istiqamah. (2011). Hukum Perdata di Indonesia. Makassar: Alauddin Press

[6] Kamil, Ahmad. (2012). Filsafat Kebebasan Hakim. Jakarta: Prenadamedia Group

[7] Mertokusumo, Sudikno. (1998). Hukum Acara Perdata Indonesia. Yogjakarta: Libery

[8] Ministry of National Education, Big Dictionary of Indonesian Language Center, Jakarta: PT Gramedia Pustaka Utama, 2008

[9] Ramulyo, Idris. (1996). Hukum Perkawinan Indonesia. Jakarta: Budi Aksara

[10] Soemiaty. (1999). Hukum Perkawinan Islam dan Undang-Undang Perkawinan, Yogyakarta: Liberty

[11] Syarifuddin, Amir. (2006). Hukum Perkawinan Islam di Indonesia: Antara Fiqh Munakahat dan Undang-Undang Perkawinan. Jakarta: Kencana

[12] Ummu Kalsum. (2017). Pengaruh Dispensasi kawin Terhadap Tingkat Perceraian Di Pengadilan Agama Watampone Kelas I A. Scription. Makassar: Fakulty Syariah dan Hukum UIN Alauddin

[13] Usman, Rachmadi. (2006). Aspek-Aspek Hukum Perorangan \& Kekeluargaan di Indonesia, Jakarta: Sinar Grafika

Regulations:

[1] General Elucidation of Act No. 16 of 2019 concerning Amendments to Act No. 1 of 1974 concerning Marriage

[2] Islamic Compilation Law No. 1 of 1991 
Interview:

[1] Interview with the Head of the Religious Courts and Judges of the Religious Courts in the work unit of the High Religious Courts in Central Java

[2] Electronic Interview with Dra. Hj. Sri Rokhmani, MHI, Deputy Chairman of the Pemalang Religious Court, Kebumen, 3 September 2020.

[3] Electronic Interview with Drs. H. Ahmad Husni Tamrin, MH, Deputy Chairman of the Kebumen Religious Court, Kebumen, 3 September 2020.

[4] Electronic Interview with Drs. Muhammad Dihyah Wahid, Head of the Temanggung Religious Court, Temanggung, 2 September 2020.

[5] Electronic Interview with Uray Gapima Aprianto, S.Ag. MH, Chair of the Kajen Religious Court, Kajen, 3 September 2020. 